\title{
State and System: The Rise of Plastic Racism Through Capitalism
}

\author{
Antonio Lopez \\ PhD Researcher, University of Deusto, Spain
}

\begin{abstract}
Although there are numerous investigations regarding state racism, studies are absent regarding discrimination created by the social system. Indeed, nation-states continue to be the best analytical tool concerning migration policies and racial narratives. National behavior responds to the needs of the global economic system, although maintains a certain margin of action regarding the improvisation of racial policies. Commonly, the analysis of racism articulated through the nation-states has presented investigative deficiencies by not addressing the causes that justify their needs. The present research suggests that nation-states' domestic policies regarding racism primarily embody a cultural conflict between social classes. Likewise, it is suggested that the conflict between classes constitutes a need of the entire social system that arises from the commitment to racialize human groups of workers. However, the present study should be expanded, mainly through an analysis of the social situation of native workers assimilated in societies traditionally receiving immigration.
\end{abstract}

Keywords: class conflict; guest-workers; immigrant workers; racialization; temporary labor. 


\section{Introduction}

The role of nation-states concerning the construction and reproduction of racism has been extensively analyzed. However, the role of the system concerning it has been poorly investigated. Frequently, cultural phenomena that have arisen through social systems have been analyzed within particularized historical processes (e.g., Colonialism or the Enlightenment) or through the specific needs of nation-states. Nonetheless, the social manifestations of racism can only be analyzed when linked to capitalism's plastic reorganization and understanding it as a universal economic system. In this sense, for example, the implications of Darwinian naturalism (strongly implicated with contemporary racial ideals) as a theoretical body of knowledge concerning the economic system is striking. The evolutionary principles of Darwinism were based on free trade economic assumptions but they were quickly assimilated as a holistic explanation of human cultural life. The philosophical pragmatism of Francis Hutcheson (16941746) and the mercantilist physiocratism of François Quesnay (1694-1774), among other ideals, fit adequately within the reflections of The Wealth of Nations (1776) by the Scottish economist Adam Smith (1723-1790) and Principles of Political Economy (1817) by Jewish economist David Ricardo (1772-1823). Both biological and economic conventions crystallized in the 19th century within cultural theories of human groups and their relationships. The Darwinian naturalism's insights easily connected with the social engineering of Spencerianism, the Malthus's demographic pessimism, and at the same time articulated the "modern" principles of laissez-faire capitalism, which in turn formed relatively racial perceptions.

The analysis of the relationship between cultural trends and the interest of the nation-states has neglected, occasionally, the investigation between the latter and the social system. This fact has presented unavoidable investigative absences and a lack of modern research about the issue. However, theoretical frameworks as the so-called "Castles-Kosack 1973 analysis" (also Migrant labor theory or Political economy of migration theory) presented in his 1973 work Immigrant workers and class str. in Western Europe has clarified the academic understanding of modern models of social organization and economic development. Stephen Castles and Godula Kosack, the authors of the referred work, gave birth to the role of "guest-workers" (immigrant workers,) a concept that had to be understood analytically as a "industrial reserve army" or "reserve army of labor." The existence of this "army" could unfold through different cultural stages and been analyzed through frameworks such as Postmodernity, liquid Modernity, globalization, or Marxism, although it simply constituted a "necessary" cultural phenomenon between the social system and nation-state policies. The meaning of the "guestworkers" as an explanatory principle that exceeds the limits of cultural stages is crucial. Likewise, it surpasses the function of nation-states and nationalism when the objective is to explain the nature of contemporary racism, even though the relevance of "guest-workers" is intimately involved with them. Given this analytical context, the present research suggests that the States' needs correspond to the needs of the system, although the former is capable of creating, articulating, and reproducing racism through the creation and definition of cultural strategies - just as they do with other social aversions such as classism or sexism. 


\section{Relationship between nation states and system}

The idiosyncrasy of modern states about racism and its relation to the social system is a crucial question. In this sense, it is also one of the most complex objects of study within the social sciences. Different contemporary authors have expressed their thoughts regarding their role and significance. Western states have shown themselves as the most comprehensive units of analysis in producing human displacement and dispossession (Bacon, 2013; Cross, 2013; Hanieh, 2013; Choudry and Smith, 2016,) which has not prevented an enormous difficulty in its analysis. Modern nation-states build different agencies with different interests, autonomy, and action capacity (Boswell, 2007, p. 79.) However, through them can be understood its policies and future prospects (Boswell, 2007, p. 95.) Exeter University scholar Adam Hanieh argues that:

There have been major transformations in how borders and migration policy operate across the world over recent times, including: (1) the securitization of borders; (2) the growing weight of private capital in migration and border management; and (3) so-called extraterritorialization, where responsibility for border controls is increasingly offloaded to third countries. These changes have occurred as part of the mantra of 'managed migration' that continues to dominate policy-making circles across the world [...] (Hanieh, 2019, p. 52.)

The problem that liberal states face against racism lies in their internal contradictions. Its nature has been constructed to reproduce the interests of the ruling classes and, at the same time, these interests are opposed to the demands for justice made by the dominated classes, which contradictorily develop the social reproduction of the ruling class through its workforce. In the current social framework, racial contradictions constitute complete moral nonsense. Given this cultural context, "bourgeois equality" exposes narratives and reifies accounts related to universalism, peace, and rational justice. Meanwhile, capital accumulation constitutes an insurmountable contradiction, an economical and vital principle beyond any moral nature, since the ruling classes are always willing to racialize any human group with the aim of enriching the privileges of the former. Capital accumulation expands the chances of prospering through access to legal capacity, and the primary social tool used in the cultural context is the conceptual assignment of the estate value of human groups. The result of a life based on these precepts is a perpetual social contradiction, mainly between the universalism of the system and the preservation of particular values by the State and individuals (Wallerstein, 1991; Glick-Schiller and Salazar, 2013; Samers, 2016.) The worldview of a system necessarily tends to reject particularities to reproduce the needs of the system, and in this sense, as it has been criticized:

[...] racial exploitation and race prejudice developed among Europeans with the rise of capitalism and nationalism, and that because of the world-wide ramifications of capitalism, all 
racial antagonisms can be traced to the policies and attitudes of the leading capitalist people, the white people of Europe and North America (Cox, 1948, p. 322.)

Gradually, the original nature of nation-states has lost its meaning - especially with the loss of exercise of power in favor of private companies from the 1970s. In this way, nationalism no longer represents the sensitivity of nations, but it needs to pretend that it does, including especially the particularities of the culture. On the contrary, national sensibility constitutes an alibi for reproducing the needs of the system itself while symbols, narratives, and rites are reified through the plastic idea of "tradition." But this "tradition" only serves as an intratextual channel for the reproduction of capital, and the great masses of guest-workers have become a directly constituent element of the possibilities of expanding it through the workforce. Nationstates offer certain advantages to the system as intermediate social for the treatment, organization and location of these masses of guest-workers. For example, nation-states offer the social impression that government policies are constantly necessary, channel hatred on a broad group of people to blame for "national" evils, while ideally suggest that governments have an essential civil function. But significantly, the forms of self-government of nation-states have developed two objectives concerning racism. The first has been to reify their own existence by guaranteeing the monopoly of civil security. The second is to offer the impression that they can resolve the contradictions in favor of the dominant electorate, the hegemonic civil layers, and the interests of privileged social classes.

\section{Capitalism as a producer of racism}

Considering racism as a necessary phenomenon of capitalism implies estimating the working class as a homogeneous bloc capable of being divided by the elites. Among many other division objectives, given certain palpable intersections of oppression such as language, worship, or phenotype, the difference between immigrants and natives helps system development goals. Various authors have exposed theoretically how large masses of migrants are capable of creating a valid subjective illusion for short-term political interests (De Genova, 2013; Kolankiewicz and Sager, 2021; Dehm and Silverstein, 2021.) However, the constant production of racial views about human groups has other implications and consequences. The system needs to standardize hegemonic patterns on which to support global ideals. The primary social tool to achieve this objective is legality, a form of civil exercise capable of differentiating what takes place within the system from what takes place in parallel with it. Following in the wake of the systems, the nation-states channel what is shown to be non-symmetrical, categorizing it as illegal. Nation-states then show what is "illegal" while guarantees that there is also something "legal." A human group that defines cultural strategies respects another group tends to act cohesively, and a social group reifies itself as orthodox as long as it can differentiate what is institutionally different. Then, what is the model that the system uses to guide the differentiation between groups? This question does not have an easy answer. A complex but at the same time universal social system is characterized by its excessive and necessary complexity. Within a cultural architecture of this type, different oppressive intersections are used transversal and 
concomitantly. However, various authors in the 1970s and 1980s demonstrated how labor indicators were crucial to target discrimination by following the so-called Castles-Kosack 1973 analysis - especially within the Miles-Phizacklea 1977 paradigm (see Miles and Phizacklea, 1977a/b, 1978, 1979.) Given the nature of contemporary post-industrial capitalism, based on constant cyclical crisis processes, the plastic and mobile workforce has become an unavoidable explanatory principle. Social inclusion is firmly subordinated to temporary employment. The "guest-workers" constitute a necessary labor force but at the same time dispensable given their significant plasticity and cultural meaning. The idea of the "labor reserve army" is static for governments but the members that make up its entirety vary. In this way, its social significance and estimation is based on consumption possibilities. One of the constant characteristics of modern capitalism is its capacity to transform any systemic phenomena into capital, which was traditionally called "commodification of everything." This ontological contradiction causes feudal (e.g. "Mediterranean" Capitalism) the and slave forms (e.g. "Indian" Capitalism) of productive development to be found within Capitalism as a system. However, the State is only an "alibi" in the equation that develops an economic model based on financial instability. Nation-states can create a constant division between groups through their cultural tools, and this is the reason why it is necessary to contemplate a theoretical principle capable of explaining the connection between the nation-states and the system when they both generate racial, xenophobic, and class values. The principles proposed as "vital" elements of the union have been several, among them colonialism, biological scientism, or nationalism. But among many other theoretical approaches to the identity contemporary racism, "manifest destiny" (also called "common destiny") constitutes one of the most relevant ideas.

\section{Manifest destiny}

One of the main existing political tools concerning racialization is the collective moral projection. This type of projection can always benefit a state while seeking to connect it with the world economic system's needs. The set of terms "manifest destiny" was used for the first time in 1845 by the journalist John O'Sullivan (1813-1895) concerning American annexation possibilities - which became a famous controversy about filibusterism and continentalism. The idea of a manifest destiny occurs when a people's historical tradition coincides with the moral pretensions of its present and the executive possibilities with the civil impetus; racial legitimacy is usually subtly associated with this kind of state political needs as racialization became an easily manageable cultural phenomenon. Henceforth, sociology from a specific region would establish politically the psychological differences between "races" and their relationship with the historical destiny. As British scholar Martin Barker points out:

It is a theory of human nature. Human nature is such that it is natural to form a bounded community, a nation, aware of its differences from other nations. They are not better or worse. But feelings of antagonism will be aroused if outsiders are admitted. And there grows up a special form of connection between a nation and the place it lives (Barker, 1981, p. 21.) 
The relationship between racism and manifest destiny has been moderately discussed today (Miller, 2006; Madsen, 2010; Pfaff, 2010; Jung, Vargas y Bonilla-Silva, 2011, p. 50-51 y 6265,) especially since the 1981 work Race and Manifest Destiny by the scholar Reginald Horsman, who carried out an in-depth analysis of the providence and romanticism underlying nationalist racism. The famed British sociologist Anthony D. Smith developed a middle ground between "primordialists" and "modernists" called "ethnosymbolism" (Smith, 1971, 1988, 2009.) Smith assumed a subjective sense of commitment to the community that was not related to shared myths about a common origin but about its future aspirations. This commitment is related to idealized collective possibilities, which explains the existence of constant feelings and emerging civil movements related to nationalism that in modern times make the future mythological. Manifest destiny could be seen as a historical reality within policies such as those of the Soviet Union, Israel after 1948, the Third Reich, or practically all former British and French colonies. This impetus quickly and improperly transformed a glorious past of the future.

\section{Conclusion}

Given the breadth of the object of study treated in this work, it is not easy to define a single purpose without certain reservations. However, through the development of the body of analysis, certain conclusions could likely have been found. Among them, the social construction of human races is a consequence of class needs. The classes, in themselves, constitute a constant element of significant division between social groups. However, it is essential to note that classes do not constitute standard groupings of human collectives - although they behave socially as groups. The idea of "class" aims to encompass and primarily safeguard beneficial interests for them.

Classes guarantee a meaningful perspective within society, even containing innumerable constituent intersections within them. The intersections ultimately determine the oppressive needs of racialization. The classes' actions crystallize in dynamic processes typical of the system but are channeled by the nation-states' needs. In this sense, it should not be forgotten that cultural movements such as that derived from the Enlightenment generated an aesthetic perception in the 18th century that constituted an engine of racialization for the next two centuries. Among many other conclusions, the present study suggests that, from an analytical perspective, it is only through a theoretical framework that primarily considers plasticity that it is possible to interpret racialization processes without reservation. Likewise, these processes must be interpreted in light of the needs of the social system. Roughly speaking, this, the social system, determines the dynamism of racialization. As the world economic system has accelerated its cyclical crises, human groups are racialized at a more incredible speed and through greater irrationality. However, this does not imply that nation-states cannot act. On the contrary, their capacity for racist action and creativity is broad, and they select phenomena capable of developing their interests. 


\section{References (TNR 14pt., bold)}

Bacon, D. (2013). The Right to Stay Home: How Us Policy Drives Mexican Migration. Beacon Press.

Barker, M. (1981). The new racism. Junction Books.

Boswell C. (2007). Theorizing Migration Policy: Is There a Third Way? International Migration Review, 41(1), 75-100. doi:10.1111/j.1747-7379.2007.00057.x

Choudry, A. \& Smith, A. (2016). Unfree Labour? Struggles of Migrant and Immigrant Workers in Canada. M Press.

Cox, O. C. (1948). Caste, class and race: a study in social dynamics. Doubleday.

Cross, H. (2013). Migrants, Borders and Global Capitalism: West African Labour Mobility and EU Borders. Routledge.

De Genova, N. (2013). Spectacles of migrant 'illegality': the scene of exclusion, the obscene of inclusion. Ethnic and Racial Studies, 36(7), 1180-1198. https://doi.org/10.1080/01419870.2013.783710

Dehm, S. \& Silverstein, J. (2021). Film as an anti-asylum technique: international law, borders and the gendering of refugee subjectivities. Griffith Law Review. https://doi.org/10.1080/10383441.2020.1891609

Glick-Schiller, N. \& Salazar, N. B. (2013). Regimes of Mobility: Imaginaries and Relationalities of Power. Journal of Ethnic and Migration Studies, 39(2), http://dx.doi.org/10.1080/1369183X.2013.723253

Hanieh, A. (2013). Lineages of Revolt: Issues of Contemporary Capitalism in the Middle East. Haymarket Books.

Hanieh, A. (2019). The contradictions of global migration. Socialist Register, 55, 50-78.

Horsman, R. (1981). Race and manifest destiny. Harvard University Press.

Jung, M. K., Vargas, J. C. y Bonilla-Silva, E. (2011). State of white supremacy: racism, governance, and the United States. Stanford University Press.

Kolankiewicz, M. \& Sager, M. (2021). Clandestine migration facilitation and border spectacle: criminalisation, solidarity, contestations. Mobilities. https://doi.org/10.1080/17450101.2021.1888628

Madsen, D. L. (2010). The West and manifest destiny. En J. C. Rowe (Ed.), A Concise Companion to American Studies (pp. 369-386). Wiley-Blackwell.

Miles, R. \& Phizacklea, A. (1977a). Class, race ethnicity and political action. Political Studies, 25(4), 491-507.

Miles, R. \& Phizacklea, A. (1977b). Black workers, and New Commonwealth immigration, 1954-1973 (Working papers on Ethnic Relations, 6). University of Bristol (S.S.R.C. Research Unit on Ethnic Relations).

Miles, R. \& Phizacklea, A. (1978). The TUC and black workers 1974-1976. British Journal of Industrial Relations, 16(2), 195-207.

Miles, R. \& Phizacklea, A. (Eds.). (1979). Racism and political action in Britain. Routledge.

Miller, R. J. (2006). Native America, discovered and conquered: Thomas Jefferson, Lewis $\&$ Clark, and manifest destiny. Greenwood Publishing Group. 


\section{SOCIAL SCIENCES IN THE 21ST CENTURY}

Pfaff, W. (2010). The irony of manifest destiny: the tragedy of America's foreign policy. Walker Publishing.

Samers, M. (2016). New Guest Worker Regimes?. In Amelina A., Horvath K., Meeus B. (Eds.), An Anthology of Migration and Social Transformation: European Perspectives (pp. 121-34). Springer.

Smith, A. D. (1971). Theories of nationalism. Duckworth.

Smith, A. D. (1988). The ethnic origins of nations. Blackwell.

Smith, A. D. (2009). Ethno-symbolism and nationalism: a cultural approach. Routledge.

Wallerstein, I. (1991). The ideological tensions of capitalism: Universalism versus racism and sexism. In Balibar E., \& Wallerstein. L. (Eds.). Race, Nation, Class: Ambiguous Identities (pp. 29-36). Verso. 